\title{
Analisis Penggunaan TIK Dengan Aplikasi Dalam Pembelajaran Daring di SD N 17 Kayuagung
}

\author{
Muhammad Dhori ${ }^{1}$, Muqowim ${ }^{2}$, Tiara Nurhayati ${ }^{3}$ \\ Fakultas IImu Tarbiyah dan Keguruan, UIN Sunan Kalijaga Yogyakarta \\ 20204081008@student.uin-suka.ac.id, muqowim@uin-suka.ac.id, \\ 20204081003@student.uin-suka.ac.id
}

\begin{abstract}
This writing was made to analyze the use of ICT through applications in online learning in elementary schools during the Covid-19 pandemic. Using qualitative research methods with a descriptive approach to library research. The Covid-19 pandemic has had a huge impact on the education sector, especially in Indonesia. Where the teaching and learning process that was previously carried out in a school environment is now an online learning process that is carried out at home. The use of ICT has a significant effect on the learning process during the current pandemic. Advances in information and communication technology that have developed rapidly such as teachers can contact students using the internet through an application such as whatsapp group, google class, zoom, etc. Then the Ministry of Education and Culture has facilitated online learning for free with the distribution of free quotas to deliver elementary school level learning materials by using applications in order to help the online learning process such as the Google Classroom application and the Zoom application suitable for high class use, while the WhatsApp group application is suitable for use in low classes. When the online learning process takes place, students will still be supervised by parents/guardians and teachers so that the learning process goes wel.
\end{abstract}

Keywords : Covid-19; Online Learning; ICT.

Abstrak. Penulisan ini dibuat untuk menganalisis penggunaan TIK melalui aplikasi dalam pembelajaran daring di sekolah dasar pada masa pandemi Covid-19. Menggunakan metode penelitian kualitatif dengan pendekatan deskriptif bersifat library researt. Pandemi Covid-19 amat sangat berpengaruh untuk bidang pendidikan khususnya di Indonesia. Dimana proses belajar mengajar yang tadinya dilaksanakan dalam lingkungan sekolah sekarang proses belajar daring yang dilaksanakan dirumah sendiri. Penggunaan TIK berpengaruh signifikan pada proses pembelajaran di masa pandemi saat ini. Kemajuan teknologi informasi dan komunikasi yang telah berkembang pesat seperti guru dapat menghubungi peserta didik menggunakan internet dengan melalui sebuah aplikasi seperti whatsapp group, google class, zoom, dll. Kemudian kemendikbud telah memfasilitasi belajar daring secara gratis dengan pembagian kuota gratis untuk menyampaikan materi belajar tingkat sekolah dasar dengan menggunakan aplikasi agar dapat membantu proses pembelajaran daring seperti aplikasi google classroom dan aplikasi zoom cocok digunakan kelas tinggi sedangkan aplikasi whatshapp group cocok digunakan pada kelas rendah. Pada saat proses pembelajaran daring berlangsung peserta didik akan tetap di awasi oleh orang tua/wali dan guru supaya proses pembelajaran berjalan dengan baik.

Kata Kunci : Covid-19; Pembelajaran Daring; TIK

\section{PENDAHULUAN}

Pada saat ini virus covid-19 sangat memberikan dampak amat besar pada bidang Pendidikan. Untuk antasipasi tertularnya virus tersebut, dengan ini pemerintah mengeluarkan keputusan yaitu social distancing, pembatasan social berskala besar dan isolasi mandiri, dimana. Dengan ini seluruh elemen masyarakat melakukan baik itu pekerjaan, beribadah, belajar maupun kegiatan lainnya. Dengan banyak nya pengaruh dari wabah penyakit ini pemerintah melalui Kemendikbud dengan 
menerbitkan Surat Edaran No 4 Tahun 2020 tentang Pelaksanaan Kebijakan Pendidikan dalam Masa Darurat Penyebaran Virus Corona, didalam kebijakan ini bahwasahnya pelaksanaan pembelajaran akan dilakukan dirumah masing-masing dengan menerapkan belajar daring agar sistem pendidikan tetap memberikan pengalaman belajar dengan baik kepada peserta didik. (Astini, 2020)

Pelaksanaan pembelajaran daring bisa membantu proses pembelajaran terlaksana walaupun pada suasana pademi. Pembelajaran daring ialah sebuah proses belajar apabila murid dan guru tidak bisa bertemu langsung ketika datang di lingkungan sekolah. Penerapan pembelajaran daring bisa dilakukan dengan secara jarak jauh atau digabungkan dalam kelas (Dhori, 2021). Dalam hal ini peserta didik mampu berinteraksi dengan guru menggunakan aplikasi pembelajaran. Pembelajaran daring memiliki tujuan dalam mencapai standard pendidikan melalui penggunaan Teknologi Informasi dan Komunikasi (TIK) dengan memadukan sebuah perangkat keras atau alat komunikasi berupa smartphone yang mampu menghubungkan peserta didik dan gurunya.

Dengan penggunaan teknologi informasi dan komunikasi ini proses belajar mampu dilakukan secara baik sesuai tuntunan aturan yang berlaku. Terdapatnya teknologi informasi dan komunikasi melalui sebuah aplikasi sangat diharapkan proses belajar mampu berjalan sebagaimana mestinya, dimana dilihat dari sisi masyarakat Indonesia berdasarkan data yang dikutip dari penelitian We Are Sosial pada tahun 2020 dipaparkan terdapat 175,4 juta yang menggunakan internet di Indonesia. Dilihat dari total keseluruhan populasi Indonesia berjumlah 272,1 juta jiwa, maka dari itu terdapat $64 \%$ setengah penduduk Indonesia telah mendapatkan akses internet. Adapun aplikasi yang digunakan di dunia pendidikan Indonesia pada saat melakukan pembelajaran daring antara lain pertama e-learning, kedua whatsapp group, ketiga google dokumen, keempat google classroom, kelima google form, keenam zoom, dll. Bahkan Kemendikbud memfasilitasi sebuah aplikasi platform pembelajaran daring secara gratis yakni "Rumah Belajar". Didaerah yang kurang baik internetnya pemerintah berkerja sama dengan TVRI atau stasiun televisi lainya untuk penyampaian materi pembelajaran dalam program belajar dirumah. Pada tingkat sekolah dasar atau madrasah ibtidaiyah untuk kelas atas aplikasi yang dipakai untuk pembelajaran daring ialah aplikasi zoom dan google classroom sedangkan untuk kelas bawah aplikasi dipakai ialah whatshapp group yang mana harus dilaksaakan dalam pengawasan orang tua dan pendidik.

Dalam penggunaan teknologi informasi dan komunikasi dalam aplikasi yang dapat dimanfaatkan sebagai media pembelajaran hal ini merupakan sebuah inovasi digunakan dalam proses belajar mengajar, selain penjelasan materi pembelajaran akan tetapi menjadi sebuah perubahan kemampuan murid dengan berbagai keahliannya (Setyaningsih, 2020). Penggunaan teknologi informasi dan komunikasi merupakan solusi dari sistem pembelajaran yang bisa memberikan pembelajaran pada siswa dengan memakai media internet yang bisa dipakai pada saat pembelajaran berlangsung. Dalam penggunaan aplikasi ini sangat cocok dipakai pada masa pandemi pada saat ini, sebab aplikasi tersebut mampu digunakan oleh semua kalangan pendidikan khususnya pada anak sd/mi dalam bimbingan orang tua dengan harapan pembelajaran mampu terlaksanakan dengan baik. (Putri et al., n.d.).

Kelebihan pembelajaran daring menurut (Daryanto, 2011) yakni pertama terdapat fasilitas sarana dan prasarana seperti aplikasi pembelajaran di mana guru dan murid mampu berinteraksi secara mudah tanpat ada yang menghalangi baik itu dari jarak, waktu, bahkan tempat. Kedua murid mampu mengkaji bahan pelajaran setiap waktu sehingga dimana pun berada bias diakses. Ketiga apabila murid membutuhkan sebuah informasi berkaitan dengan pembelajaran, murid mampu mengakses informasi tersebut melalui aplikasi. Keempat guru dan murid mampu melaksanakan diskusi dengan aplikasi tersebut dan bisa diikuti seluruh murid, sehingga mampu mengimbangi dengan adanya jumlah siswa yang banyak, dan mampu menambah ilmu pengetahuan serta wawasan murid tersebut. Kemudian dalam pembelajaran daring memiliki kekurangan yaitu terdapat kurangnya sebuah komunikasi antara guru dan siswa atau bahkan sesama siswa bisa menghambat proses pembelajaran, dan murid yang belum memiliki sebuah keinginan belajar cenderung akan gagal. 
Jadi aplikasi pembelajaran ini digunakan untuk alat komunikasi, tempat berdiskusi, penyetoran tugas dan penyampaian pembelajaran oleh pendidik kepada siswa pada masa pandemik Covid-19 di SD/MI. Dari permasalahan yang telah diungkapkan yang paling penting juga adanya integrasi memanfaatkan tekologi dengan masa pandemi saat ini. Integrasi teknologi ini dengan pembelajaran sebuah usaha dalam menggabungkan teknologi dengan teori pembelajaran agar proses pembelajaran daring saat ini mampu berjalan dengan baik dengan menghasilakn strategi baru dalam pembelajaran. Tujuan penelitian ini ialah untuk mengetahui penggunaan dari TIK dalam proses pembelajaran daring pada masa pandemi di SDN 17 Kayuagung.

\section{METODE PENELITIAN}

Menggunakan penelitian kualitatif dengan metode literatur dan metode wawancara (Sugiyono, 2016). Penelitian literatur ialah sebuah penelitian yang mengumpulkan sebuah informasi dan data yang dibantuan oleh kajian yang pernah ada. Kemudian langkah yang digunakan oleh penulis yakni pertama mencari suatu referensi dengan memakai kata kunci dari judul jurnal tersebut, kemudian terdapat sebuah referensi yang cocok dan penulis akan memahami teori tersebut serta memprasekan menggunakan kata sendiri. Untuk mendukung data literatur ini harus dilaksanakan wawancara mendalam kepada guru yang bersangkutan di SDN 17 Kayuagung total ada 14 orang. Kemudian data didapat dari kajian literatur dan wawancara lalu dibuat dalam bentuk narasi agar mendapatkan sebuah penjelasan umum mengenai pemanfaatan TIK dalam pembelajaran daring pada masa pandemi saat ini.

\section{HASIL PENELITIAN DAN PEMBAHASAN}

Dengan munculnya wabah penyakit Covid-19 ini maka seluruh proses pembelajaran yang mana semula dilakukan di lingkungan sekolah namun berubah menjadi melakukan pembelajaran di rumah masing-masing dengan melalui pembelajaran daring. Pembelajaran daring dilaksanakan dan disesuaikan dengan kemampuan setiap sekolah tersebut. Pembelajaran daring bisa digunakan melalui aplikasi teknologi informasi dan komunikasi seperti rumah belajar, google classroom, google documen, google form, video converen, zoom, dll. Menurut (Pakpahan \& Fitriani, 2020) pembelajaran daring merupakan pembelajaran terbuka dan terluas dalam menggenakan sebuah alat canggih untuk membantu pendidikan, yang kemungkinan berkaitan sama internet serta teknologi informasi dan komunikasi berbasis jaringan dalam menyediakan sebuah bentuk proses pembelajaran dan pengetahuan melalui suatu yang berarti. Menurut (Hartanto, 2016) Pembelajaran daring dapat menggunakan aplikasi pembelajaran salah satu nya elearning yang terdapat dua bagian yakni: Synchronous. Synchronous yaitu dilaksanakan pada waktu yang bersamaan. Dalam proses belajar akan terjadi saat bersamaan antara guru dan murid. Karna membuat interaksi secara langsung antara guru dan murid secara daring.

Dalam penggunaannya, synchronous mewajibkan guru dan murid untuk secara bersama mengakses internet melalui aplikasi. Guru memberikan sebuah materi belajar dalam bentuk slide presentasi atau file dan murid mampu memahami serta mendengarkan presentasi secara langsung melalui aplikasi pembelajaran. Murid juga bisa menanyakan pertanyaan dengan langsung sesuai aturannya. Synchronous ialah sebuah gambaran pembelajaran langsung tetapi ini hanya bersifat virtual dan seluruh murid terhubung melalui internet dengan aplikasi. Aplikasi yang dipakai yakni zoom, google classroom, dan whatshapp group. Dan kemudian ada Asynchronous yaitu tidak dilaksanakan pada waktu secara bersama. Murid bisa membuat waktu belajar berbeda dengan guru pada saat pemberian materi belajar contohnya ruang guru, kelas pintar, google form dan zenius. Asynchronous dikenal didalam elearning sebab murid mampu mengakses atau melihat materi belajar dimanapun berada. Murid mampu melaksanakan belajar dan mampu menyelesaikan sesuai jadwal yang direncanakan. Pembelajaran ini dapat berupa sebuah bacaan, simulasi, animsi, permainan edukasi, quis, tes, serta pengumpulan tugas (Utami, 2020).

Kementerian Pendidikan dan Kebudayaan memberikan kebebasan para sekolah dalam menggunakan aplikasi platform belajar daring (Kemendikbud, 2020). Namun, untuk membantu 
proses pembelajaran agar lebih maksimal dalam belajar, Kemendikbud memberikan fasilitas aplikasi prmbelajaran daring dengan gratis yakni Rumah Belajar dan aplikasi platform untuk pendidik yakni Program Guru Berbagi. Rumah Belajar memberikan bahan pembelajaran dan alat komunikasi para pemakaianya, kemudian Program Guru Berbagi menyediakan RPP bagi pendidik. Bagi yang tinggal didaerah yang jaringan internetnya kurang stabil, disini pemerintah sudah bekerja sama dengan stasiun TVRI atau stasiun televisi, dalam memberikan sebuah materi pembelajaran di dalam program belajar di rumah selama masa pandemi ini (Kholida \& Suprianto, 2020).

Dengan demikian yang harus dilaksanakan ialah memberikan sebuah tugas melalui pemantauan pendampingan oleh pendidik dengan aplikasi whatsapp grup agar peserta didik serius dalam belajar nya. Lalu pendidik harus bekerja dari rumah dan saling koordinasi atau komunikasi terhadap wali siswa, baik itu melalui whatsapp, telephone, ataupun dokumentasi pada saat pembelajaran daring berlangsung supaya adanya sebuah interaksi pendidik dan wali siswa tersebut. Pada masa pademi ini peranan wali siswa dalam pelaksanaan pembelajaran dirumah amatlah penting.

Pembelajaran daring harus ditekankan kepada wali siswa bisa memakai aplikasi tersebut, dengan demikian siap tidak siapnya wajib melaksanakan pembelajaran dan siap menajadi pengajar melalui daring dengan aplikasi tersebut. Kemudian wali siswa menyediakan bahan dan sistem pembelajaran daring serta mampu membimbing terhadap anak supaya bisa memakai teknologi informasi dan komunikasi dengan aplikasi untuk pembelajaran agar meningkatnya kualitas pengetahuan peserta didik (Rokhimah, 2021). Wali siswa mampu apresiatif dan bisa menggunakan aplikasi dalam mendidik anaknya belajar daring dari rumah masing-masing. Sebab pembelajaran daring bisa dilakukan dengan lancar jika terdapat suatu peranan wali siswa yang maksimal dalam membimbing anaknya. Pada masa pandemi ini sangat dituntut wali siswa, pendidik dan siswanya wajib mampu mengunakan aplikasi tersebut. Ada beberapa aplikasi dipakai oleh pendidik sekolah pada saat proses belajar daring dirumah yaitu e-learning, whatshapp, google form, google document, zoom, google classroom, dll (Hakim, 2016).

Dalam proses pembelajaran melalui google classroom di sekolah cocok digunakan pada peserta didik yang berada pada kelas atas. Peserta didik dalam kelas atas mempunyai keinginan kehidupan yang praktis dalam sehari nya. Menurut (Wicaksono \& Rachmadyanti, 2017) peserta didik pada kelas atas terlihat tahap, mencoba, ekperimen dan menyelidik. Peserta didik pada usia ini sudah mampu menggunakan aplikasi tersebut, yang mana dalam zaman sekarang ini teknologi sudah sangat maju berkembang. Pendidik bisa menggunakan berbagai aplikasi yang pada google classroom antara lain assigments, archive course, communication, mobile applications, grading, time-cost dan privacy. Kemudian difokuskan ketika melaksanakan google classroom, pendidik alangkah baiknya memberikan sebuah pemahaman terlebih dahulu terhadap wali siswa supaya tidak akan terjadi kesalahpahaman didalam pembelajaran nanti. Selanjutnya guru memberikan proses pelatihan terhadap murid tentang bagaimana pelaksanaan pada aplikasi google classroom sebagai tahapan perkenalan manfaat dari aplikasi ini.

Dalam aplikasi ini dapat menggabungkan dan mensinergikan seluruh alat media yang diataranya dari animasi, music, teks, narasi, foto, video, grafis dan interaksi yang diprogram melalui teori pembelajaran. Proses pembelajaran melalui aplikasi pembelajaran mampu membuat peserta didik bisa melaksanakan pembelajaran menggunakan kemampuan berfikir, keterampilan, kreativitas dan membangun konsep. Dengan ini sesuai sama prinsip teknologi informasi dan komunikasi dalam diri peserta didik yang akan dilaksanakan dalam interaksi berdasarkan prinsip yaitu: Pertama, ilmu pengetahuan yang tersusun. Kedua, meningkatnya kreativitas peserta didik. Ketiga dapat mengidentifikasi diri dalam aplikasi. Keempat, penghargaan terhadap perkembangan teknologi. (Fajrin \& Muqowim, 2020)

Kemudian menurut Heru Purnomo didalam pikiran rakyat media network bahwasahnya belajar daring dengan menerapkan metode pemberian tugas secara daring bagi peserta didik melalui whatsapp grup dinilai sesuai dengan kondisi saat ini. Banyak pendidik menerapkan cara seperti ini dan berbagai macam walaupun terdapat perbedaan pembelajaran akan tetapi masih tertuju dalam 
pembelajaran. Berbagai macam yang digunakan dalam metode seperti ceramah melalui aplikasi, tetap mengajar dari sekolah dengan melalui aplikasi, pendidik juga ada yang membuat video sebagi alat peraga nya, lalu ada menggunakan sebuah konten gratis dari berbagai sumber (Ashari, 2020).

Kemudian dari hasil wawancara bersama Ibu Elmanani Guru Sekolah Dasar di SD Negeri 17 Kayuagung beliau menyebutkan pada masa pandemi ini untuk proses pembelajaran daring lebih cocok dan sesuai menggunakan aplikasi whatshapp, google form, google classroom untuk semua tingkatan kelas dan aplikasi zoom lebih cocok ditingkatan kelas atas sebab siswa sudah banyak mengerti dalam menggunakan nya. Walaupun sudah ada cara ini dalam mengatasi pandemi ini masih saja para siswa perlu dibimbing dalam pelaksanaan pembelajaran. Disisi lain selain menggunakan aplikasi tersebut masih juga terdapat hambatan dalam pembelajaran salah satu nya dari peran orang tua atau wali siswa sebab masih ada yang belum bisa menggunakan aplikasi tersebut ditambah siswa nya yang masih awam dalam penggunaan nya, akan tetapi semua ini butuh proses agar berjalan dengan baik, dari menggunakan aplikasi tersebut kita juga menggunakan bantuan dari video pembelajaran dalam menyampaikan tugas dan materi serta kita meminta siswa untuk membuat video pembelajaran mereka dan akan dikirim melalui aplikasi tersebut.

Pembelajaran daring merupakan sebuah solusi yang sangat efektif dan efisien dalam pelaksanaan pembelajaran namum perlu dilihat pembelajaran ini belum bisa dilaksanakan seluruh anak sebab dari hasil wawancara Ibu Elmanani bahwasanya masih ada anak yang belum bisa mengikuti proses pembelajaran disebabkan beberapa faktor salah satunya siswa bernama Ayu Purnama seperti tidak adanya handphone android pada saat melakukan pembelajaran daring karna faktor dari segi ekonomi masih belum mamadai akan tetapi hal ini bukan lah menjadi alasan untuk tidak belajar, sekolah juga memberikan intruksi khusus agar para pendidik yang datang langsung kerumah siswa yang membutuhkan agar dapat melakukan proses pembelajaran. Disisi lain siswa bernama Bagas juga belum mampu menggunakan aplikasi seperti zoom sebab aplikasi ini membutuhkan internet untuk menggunakan nya serta tidak adanya akses internet yang stabil hal ini amat menggangu dalam pembelajaran akan tetapi kebanyakan dari siswa sangat antusias dalam menggunakan aplikasi sebab bisa tatap muka langsung walaupun secara daring hal ini bisa membuat siswa lebih cepat paham dan mengerti lalu ada orang tua yang belum bisa menemani anak nya dalam melaksanakan pembelajaran disebabkan tuntutan pekerjaan yang tidak bisa ditinggalkan.

\section{KESIMPULAN}

Berdasarkan pembahasan diatas bahwa Pandemi Covid-19 berdampak amat besar di bidang pendidikan khusus nya di Indonesia. Dengan ini pemerintah mengambil langkah bijak mewajibkan bekerja di rumah, belajar di rumah, dan ibadah di rumah. Keadaan ini membuat satuan pendidikan dapat melaksankan inovasi terbaru pada kegiatan belajar mengajar. Adapun bentuk nyata inovasi ini adalah melaksanakan pembelajaran secara daring atau online. Pada awalnya pembelajaran dilaksankan dalam lingkungan sekolah namun ini sudah berubah menjadi belajar di rumah dengan daring. Dengan memanfaatkan teknologi ini mampu membantu setiap kegiatan belajar jarak jauh pada masa pandemi ini agar seluruh kegiatan pembelajaran mampu terlaksankan dengan baik sesuai aturan yang berlaku. Dengan adanya kecanggihan teknologi saat ini, jaringan internet mampu menghubungkan peserta didik terhadap guru nya dengan menggunakan sebuah aplikasi yaikni whatsapp group, zoom, google classroom, dll. Selain itu Kemendikbud sudah menyiapkan aplikasi belajar daring secara gratis yakni Rumah Belajar dan aplikasi bagi guru. Untuk kelas atas aplikasi yang cocok dipakai dalam pembelajaran ialah zoom dan google classroom, kemudian untuk kelas rendah yang cocok ialah whatsapp group. Akan tetapi pembelajaran online yang dilakukan oleh siswa tidak boleh lepas dalam pengawasan dari guru dan kedua orang tua nya. Agar mampu menciptakan pembelajaran efektif dengan kolaborasi guru dan orang tua siswa dalam proses pembelajaran ini. 


\section{DAFTAR PUSTAKA}

Ashari, M. (2020). Proses Pembelajaran Daring di Tengah Antisipasi Penyebaran Virus Corona Dinilai Belum Maksimal.

Astini, N. K. S. (2020). Pemanfaatan teknologi informasi dalam pembelajaran tingkat sekolah dasar pada masa pandemi covid-19. Lampuhyang, 11(2), 13-25.

Daryanto. (2011). Media Pembelajaran. PT Sarana Tutorial Nurani Sejahtera.

Dhori, M. (2021). Analisis Teori Belajar Behavioristik dalam Proses Belajar Mengajar di SD Negeri 7 Kayuagung. HEUTAGOGIA: Journal of Islamic Education, 1(1), 110-124.

Fajrin, L., \& Muqowim, M. (2020). PROBLEMATIKA PENGINTEGRASI NILAI-NILAI KEISLAMAN PADA PEMBELAJARAN IPA DI MI MIFTAHUL HUDA JEPARA. ELEMENTARY: Islamic Teacher Journal, $8(2), 295-312$.

Hakim, A. B. (2016). Efektifitas Penggunaan E-Learning Moodle, Google Classroom Dan Edmodo. Vol, $2,1-6$.

Hartanto, W. (2016). Penggunaan e-learning sebagai media pembelajaran. Jurnal Pendidikan Ekonomi: Jurnal IImiah IImu Pendidikan, IImu Ekonomi Dan Ilmu Sosial, 10(1).

Kemendikbud. (2020). Surat Edaran Nomor 15 Tahun 2020 Tentang Pedoman Penyelenggaraan Belajar Dari Rumah dalam Masa Darurat Penyebaran Corona Yirus D/Sease (Covid-19). Kementriann Pendidikan dan Kebudayaan.

Kholida, S. I., \& Suprianto, S. (2020). KETERCAPAIAN HASIL BELAJAR MAHASISWA PADA MATA KULIAH STRATEGI PEMBELAJARAN MELALUI MODEL PJBL DENGAN BERBANTUAN APLIKASI ZOOM DAN DI WHATSAPP MESSENGER. MASA PANDEMIC COVID-19. Prosiding Seminar Pendidikan Fisika FITK UNSIQ, 2(1), 280-286.

Pakpahan, R., \& Fitriani, Y. (2020). Analisa pemanfaatan teknologi informasi dalam pembelajaran jarak jauh di tengah pandemi virus corona covid-19. Journal of Information System, Applied, Management, Accounting and Research, 4(2), 30-36.

Putri, R. D. P., Nurhayati, T., \& Dhori, M. (n.d.). Analisis Pemanfaatan Teknologi Informasi dan Komunikasi dalam Pembelajaran di Sekolah Dasar Pada Masa Pandemi Covid-19. Jurnal Amal Pendidikan, 2(1), 31-38.

Rokhimah, I. M. (2021). Analisis Keterampilan Menulis Siswa Kelas 1 Pada Model Pembelajaran Dalam Jaringan (Daring) di SD Muhammadiyah 4 Surabaya. Equilibrium: Jurnal Pendidikan, 9(2), 150-160.

Setyaningsih, K. D. (2020). ANALISIS PELAKSANAAN PEMBELAJARAN JARAK JAUH DI SD NEGERI KARANGRENA 03. Jurnal Riset Pendidikan Dasar (JRPD), 1(2).

Sugiyono. (2016). Metode Penelitian Pendidikan. Alphabet.

Utami, V. A. (2020). A PENGINTEGRASIAN NILAI-NILAI KEISLAMAN DENGAN PEMBELAJARAN TIK (TEKNOLOGI INFORMASI DAN KOMUNIKASI) PADA SISWA SEKOLAH DASAR. JEMARI (Jurnal Edukasi Madrasah Ibtidaiyah), 2(2), 76-83.

Wicaksono, V. D., \& Rachmadyanti, P. (2017). Pembelajaran blended learning melalui google classroom di sekolah dasar. 